\title{
Criminally Bad Management
}

\author{
Samuel W. Buell \\ Research HANDBOOK ON CORPORATE CRIME \\ AND FINANCIAL MisDEALING (J. Arlen ed. forthcoming 2017)
}

\begin{abstract}
Because of their leverage over employees, corporate managers are prime targets for incentives to control corporate crime, even when managers do not themselves commit crimes. Moreover, the collective actions of corporate managementproducing what is sometimes referred to as corporate culturecan be the cause of corporate crime, not just a locus of the failure to control it. Because civil liability and private compensation arrangements have limited effects on management behaviorand because the problem is, after all, crime-criminal law is often expected to intervene. This chapter offers a functional explanation for corporate criminal liability: individual criminal liability cannot effectively address the relationship between senior managers and corporate crime but corporate criminal liability can, at least in part. Thus the practice of corporate criminal liability has grown and will continue to do so, at least in the absence of major restructuring of criminal law.
\end{abstract}

\section{Introduction}

Few would disagree that malfeasance committed within large corporations can inflict outsized harms on the public; that it occurs within complex, diverse, and often opaque institutional contexts; and, therefore, that it calls for particularized and determined regulatory responses.

Most who have thought about this problem would concede that the role of corporate managers is a central point of intervention for law: a locus to which wrongdoing often can be traced and where deterrent messages can achieve leverage given that managers wield disproportionate power within firms. American corporate law, regimes of securities regulation, and many other systems of regulation designed with the corporation in mind proceed from these premises. This point about directing incentives towards corporate managers is only more important, while also trickier to get right, when managers do not personally commit the relevant delicts - a scenario that has been repeating in very large

· Bernard M. Fishman Professor of Law, Duke University. buell@law.duke.edu. For exceptionally helpful comments, many thanks to Jennifer Arlen, Mark Osiel, J.J. Prescott, and Dan Richman. Thanks also for help from the participants in an April 2015 conference of the NYU Center on Corporate Compliance and Enforcement and a faculty workshop at the University of Iowa College of Law. 
firms, particularly those that are publicly traded and operated under complex and layered governance and compensation regimes.

Furthermore, when corporate malfeasance implicates arguments about criminal punishment - either because the wrongdoing is plainly criminal according to existing legal definitions, or because reformers might call for using the special potency of criminal sanctions - the role of managers can present a particular problem. Especially in the repeating systemic breakdowns of recent years, corporate managers often bear serious responsibility for what happened but were not involved in crime, either as direct perpetrators or as fully complicit accomplices or conspirators. Conventional legal doctrines, for good reasons, do not authorize personal criminal sanctions. Some special doctrines of supervisory criminal liability exist but they are controversial and, to date, have been narrowly tailored.

The law, of course, has other tools available for influencing management behavior, both directly and indirectly. Only one of those tools, however, can claim the label "criminal" and can mobilize a criminal justice process with all that entails, including the core idea of punishment. That tool is corporate criminal liability. It is criminal. It is a form of punishment. And it is directed, in important part, towards managers of firms. Or so this chapter will suggest.

The argument that follows is not intended as a knock down case in favor of corporate criminal liability. The literature on that question is beyond voluminous and I am guilty of having contributed to the overweight (DiMento et al. 2000, Buell 2006, 2016). Suffice it to say that no conclusive argument has been recorded for or against corporate criminal liability and none is likely to be discovered in the short term.

The objective here is to identify one underappreciated benefit of corporate criminal liability, and to make a modest normative claim from there. Crucial to any understanding of corporate criminal liability is recognizing that, as currently practiced in the United States, the doctrine and its enforcement have developed organically-largely through the collective and incremental practices of enforcement authorities and the bar-to fill a gap between criminal law and corporate regulation.

Understanding the nature of this gap, and the reasons for it, is essential to giving corporate criminal liability its due, something it has not always received in recent commentary. The doctrine's tenacity and its growth in practice can be understood as a natural response to the problem of how to influence, and even punish, corporate managers in relation to corporate crime.

The modest normative extension of this point will be to say that corporate criminal liability might be a second-best measure for dealing with management responsibility for corporate crime, given that individual criminal liability comes 
up short. This claim does not come close to settling the debate over corporate criminal liability in the United States. It is riddled with empirical uncertainties, as are competing claims. Arguments holding that forms of civil liability could fill the gap just as well, at least if one could redesign regulatory systems from scratch, remain plausible.

But the current legal landscape should be taken as evidence for something about the function of corporate criminal liability. It also must be accepted as the context in which the law will manage the next fiasco of corporate malfeasance that arises today or tomorrow.

Corporate criminal liability is a useful existing tool for responding to the problem of what might be called criminally bad management. To show this, Section 2 will describe the problem, mostly by way of examples; Section 3 will describe the demand for criminal liability and punishment in the corporate context; Section 4 will explain the limitations of individual criminal liability in satisfying that demand; and Section 5 will show how corporate criminal liability fills the gap.

\section{The Nature of the Problem}

\subsection{MANAGEMENT FAILURE AND CORPORATE CRIME}

In a great many of the recent cases of corporate malfeasance that have worried both the American public and those who work in legal institutions, the facts could not speak more clearly to the responsibility of management for damaging acts of misconduct committed by mid and lower-level employees. Managers of the companies embroiled in these scandals struck the wrong balance, to say the least, between quarterly earnings and compliance - between corporate offense and defense - with disastrous and, in hindsight, predictable results. Yet in nearly all of these cases it is equally clear that senior managers committed no serious crimes themselves - at least in the sense of having violated the terms of American criminal prohibitions, even if they might have done things the public would understandably want to call "criminal."

There is a clear relationship between corporate management, indeed bad corporate management, and corporate crime. It is a relationship that arises from the nature of the large, complex institution, especially the for-profit firm. It is not one, however, within the boundaries of conventional concepts of criminal liability.

Economic analysis of corporate regulation has usually understood this relationship as having to do with management not preventing corporate crime-as a failure of internal or private policing (Arlen and Kraakman 1997, Kornhauser 1982, Sykes 1984). This is what is encompassed by the common and now banal terminology of "compliance" (Miller 2014, Baer 2009). 
This understanding is incomplete. In many scandals of corporate malfeasance, especially the ones that worry the public the most, the failure of management is not just a failure to prevent crime. It also includes complicityand therefore desert of blame - in the production or fostering or tolerance of a corporate environment that was, to borrow a term in vogue with street crime, criminogenic (Laufer 1994). Managers did not just fail to constrain the natural impulse in the corporate context to violate the law for profit. They helped it along.

This perspective brings into the analysis of corporate wrongdoing the notoriously elusive concept of "corporate culture" (Bucy 1990). Culture eludes theorizing because it is complex, diverse, and deeply contingent on fact. There can be no dispute, however, that culture is real and that corporate managers bear responsibility for it.

\subsection{CONTEMPORARY EXAMPLES}

The relationship of managers to corporate crime can be seen more clearly through examples. Consider four recent ones.

\subsubsection{BP}

On April 20, 2010, BP's Deepwater Horizon rig exploded in the Gulf of Mexico, killing eleven people and releasing millions of barrels of crude oil into one of the world's most economically important ecosystems. ${ }^{1}$ If professional criminals - terrorists perhaps - had done this awful deed, the story about how the disaster was caused and who should be held responsible would have been straightforward. But because a corporation did it, explanation and accountability were complex, at the levels of both actions and mental state. (The less precise term "culpability" might be better than mental state since, for purposes of institutional responsibility, the question is how to describe the collective decision making of all the relevant actors within the corporation, and corporations of course do not have states of mind.)

The best explanation for the BP affair combines immediate events with more gradual developments. The rig exploded when the men in charge of temporarily capping the well failed to call ashore for help though all signs pointed to an impending and disastrous failure. The events were not brought under control much earlier because BP did not do enough as an organization, in the Gulf or elsewhere, to prioritize accident prevention while pursuing an aggressive corporate strategy to find larger and deeper offshore oil deposits.

\footnotetext{
${ }^{1}$ See United States v. BP Exploration and Production, Inc., Crim. No. 2:12-cr-00292 (E.D. La. Nov. 14, 2012) (criminal information, plea agreement, and sentencing order); United States v. Kaluza, Crim. No. 12-265 (E.D. La. Nov. 14, 2012) (superseding indictment).
} 
Robert Kaluza and Donald Vidrine are not at the center of the public's understanding of the BP case, even though they were the two BP employees federal prosecutors said were responsible for failing to alert others to the escalating problem at the well. Kaluza and Vidrine were charged with manslaughter. A third BP employee, David Rainey, was indicted for obstruction of justice for concealing information after the accident about how much oil was flowing out of the well site on the floor of the Gulf.

Few people closely followed the prosecutions of these men, which became tied up in pretrial wrangling in federal court. That wrangling produced a victory for Kaluza and Vidrine, who persuaded the Fifth Circuit to affirm the trial court's dismissal of the maritime manslaughter charges on the ground that the federal statute does not apply to persons whose job on a vessel does not relate to navigating the craft. ${ }^{2}$ (This ruling was poor statutory interpretation deployed in a bad cause. But that is another topic.) In the end, Vidrine pled guilty to violating the Clean Water Act, Kaluza was acquitted of the same charge after a trial, and another jury acquitted Rainey of the obstruction charges.

More was at stake in this case. Observers of the BP affair rationally placed responsibility on the corporations - primarily $\mathrm{BP}$ - that owned the rig, drilled the well, profited from the enterprise, hired and trained the workers, made the critical decisions and policies about equipment and safety, and so on. Yet the trouble with blaming BP's managers is that, as in many cases of corporate crime, it is difficult to pinpoint who within the massive, bureaucratic global organization that is BP both knew enough and was in charge enough to be the correct target for blame for the Gulf spill.

This is more than a lawyer's problem, a mere difficulty of proof. It is a problem of responsibility and blame. The higher you go in BP, the more responsible the managers seem to be. (Remember how the world felt about former CEO Tony Hayward in the spring of 2010 when BP's well was dumping oil and he said he wanted "his life back"?) But responsibility does not easily translate into liability. The higher you go in BP, the less the managers knew and were involved day to day in the specific problem of the Deep Horizon rig. As one ascends the corporate ladder, the case for responsibility becomes more and more "you did a bad job of setting responsible priorities and preventing crime" and less and less "you took the following act or decision that triggered that terrible explosion and spill." Yet criminal liability usually requires just such an act.

\subsection{2. $G M$}

The case of the scandalous deaths of drivers of General Motors cars involves an even deeper thicket of causation and responsibility within a massive corporate organization (Valukas 2014). Years of engineering designs and redesigns, accident reports and reconstructions, litigation teams, and endless meetings,

${ }^{2}$ United States v. Kaluza, 780 F.3d 647 (5th Cir. 2015). 
documentation efforts, and corporate reporting chains reduce to a stunningly simple problem. The spring mechanism in the starter GM installed in some car models - the place where the key goes in - was not strong enough. When drivers knocked a leg into a key chain that had heavy doodads on it, the starter could rotate out of the run position, causing the engine to turn off and preventing the air bag from deploying, with disastrous consequences for those in the car. To date, it appears that 124 people likely died when a leg jostled a key chain in the wrong way at the wrong time. ${ }^{3}$

It is bad enough that GM would design and use a faulty starter switch when making a properly functioning one would have been so easy. It is much worse that GM's managers failed to identify this simple problem and fix it in the face of nearly nine years of lawsuits and mounting evidence that GM's cars were spontaneously shutting down on the road. All the while, they were managing a gigantic firm, one in the business of making America's most lethal consumer product, whose employees joked about how meetings predictably ended with the "GM nod" (meaning "someone should do something about that") or the "GM salute" (in which one crosses arms pointing to the persons to one's left and to one's right as the responsible parties).

There is one traditional villain in the GM story. An engineer responsible for the switch corrected the design - no doubt after realizing the problem, though he incredibly claims to have forgotten the whole thing. Yet he did not document the change or the reason it was needed, as required by company policy. The engineer's concealment suppressed what would have been a red flag, thus keeping GM lawyers and investigators off the trail of the bad starter switch and greatly prolonging the problem.

But many others at GM were responsible for the fatally flawed switch and GM's failure to discover and act on the cause of all the deadly accidents. Those responsible included numerous lawyers at the company who tracked the relevant lawsuits as well as senior managers at GM who presided over an organization in which such a major problem could develop over such a long time without anyone thinking to raise the alarm with top executives. Even the General Counsel was not told.

Assume for the sake of argument - there is certainly one to be made - that what was done at GM that killed those drivers deserves, generally speaking, to be treated as a crime. Who is the criminal at GM? One could perhaps imagine that, with more facts, there might be a legal theory on which to prosecute the engineer who concealed the change in switch design. But that would hardly seem like an appropriate end to the matter at GM-just as prosecuting the rig engineers alone at BP would not have been an adequate response to the Gulf spill.

\footnotetext{
${ }^{3}$ Chris Isidore, Death Toll for GM Ignition Switch: 124, CNN MonEY, Dec. 10, 2015.
} 
One can go up the management chain at GM, just as one could at BP, but the problem at GM, even more than at BP, is one of "you should have been a better corporate manager, your communication channels were lousy." When it comes to the approach to safety that resulted in deaths, the culpability of GM senior managers, even more than for BP's top executives, is for sins of omission rather than commission.

\subsubsection{JP Morgan}

Then there is the case of the group of traders at JP Morgan that included Bruno Iksil, who became known as the "London Whale." 4 Those traders managed a profitable book of derivative securities that earned the bank as much as $\$ 1$ billion annually. Like all successful traders in the highly competitive investment banking industry, they were well compensated with bonuses tied to the profits they generated for the bank.

When the market for their products turned rather suddenly against them in 2012, the traders knew they had a large quantity of securities on their books that should be marked down - in an amount that later resulted in nearly a billion dollar loss on JP Morgan's publicly reported financial statements. Instead of reporting the truth about the plummeting value of their books internally within the bank, and thus ultimately to shareholders and the public, the key players in this trading group lied - no doubt justifying their actions with the tried and true mentality of the fraud perpetrator that the market would turn around and no one would need to be the wiser.

Investors in JP Morgan were victims of fraud because, to the tune of nearly $\$ 1$ billion, the bank gave them false information about the value of its portfolio. Senior managers at JP Morgan approved that information and its release. They also approved the compensation system that can fairly be said to have caused the traders in London to take big risks and then lie when their risks went bad. Managers also were responsible for reporting and compliance systems within the bank that did not include a means of preventing the traders from controlling how the bank valued the London derivatives book in its overall financials. But, as far as public evidence shows, the top managers at JP Morgan did not know that the numbers from the usually legitimately profitable group in London had turned massively false.

Iksil earned a nonprosecution agreement and stood ready to testify against his boss Javier Martin-Artajo. Martin-Artajo's London group primarily traded credit default swaps in a "synthetic credit portfolio." Prosecutors in the Southern District of New York must have believed that a jury would see Iksil, whale-sized

\footnotetext{
${ }^{4}$ United States v. Martin-Artajo, Crim. No. 13 Crim. 707 (S.D.N.Y. Sept. 16, 2013) (indictment); In re JPMorgan Chase \& Co., United States Secs. \& Exchange Comm'n Exchange Act Release No. 70458 (Sept. 19, 2013).
} 
trading book or not, as a junior minion who did the bidding of an overbearingly aggressive manager.

Martin-Artajo, whom the government alleges brushed away a compliance employee at the bank with, "I'm a trader, I do not mark the books to U.S. GAAP, my job is to manage risk," went to Spain. There he will likely remain, having somehow persuaded a Spanish court to deny American prosecutors' request that he be extradited to New York to be tried on charges of securities fraud. ${ }^{5}$ No one above Martin-Artajo at JP Morgan has been charged in this large, familiar, and predictable instance of accounting fraud in the marking of derivatives books by bonus-incentivized traders.

Do not expect such charges. Managers offering steep bonuses for profitable books and then inadequately monitoring those books is not, at least in the absence of proof of knowledge of serious red flags, criminal. The bank itself settled civilly with the SEC, not the Justice Department. This was one of the SEC's recent enforcement deals in which admissions of wrongdoing are required as a price of settlement. The facts admitted by JP Morgan in the SEC settlement consist of a scolding of New York management and the firm's Audit Committee for failing to implement adequate controls on the bank's trading books and having sclerosis in the reporting channels that led up to senior management. (Note that it was in 2012-years after the worst problems of the investment banking industry came to light - that these management and control deficits enabled the fiasco of the London Whale. ${ }^{6}$ )

\subsubsection{Walmart}

As a last example, consider Walmart. The retailing behemoth is reported to be in the process of negotiating a resolution with the U.S. Department of Justice over violations of the Foreign Corrupt Practices Act, which prohibits bribing foreign officials for business purposes. The core of the scandal involves revelations that Walmart operatives in Mexico paid numerous bribes to speed the approval process for constructing new stores in that country, which at the time was Walmart's fastest area of growth in the world (Barstow 2012). The bribery was a result of Walmart's relentlessly expansionist business model and its lack of effective controls on the employees driving that expansion in foreign countries.

Walmart's legal troubles have been made worse by a culture of denial and insularity at its corporate headquarters that caused Walmart to minimize and fail to pursue information about bribery in Mexico appropriately when the problem first surfaced through an internal whistleblower. Perhaps that pathology of denial related to Walmart's famously successful obsession with cost cutting. A

\footnotetext{
${ }^{5}$ Spain: Court Rejects Extradition of JP Morgan Trader, N.Y. TIMES, Apr. 23, 2015.

${ }^{6}$ If space permitted and the point about management responsibility for corporate crime needed further illustration, the major scandal in 2016 in which the bank Wells Fargo fired 5,300 employees for creating millions of fraudulent customer accounts would fit here just as well.
} 
prestigious national law firm initially recommended to corporate managers that they commission an expensive outside investigation of the company's Mexico operations. Walmart management rejected this advice, choosing wishful thinking (and an internal investigation by the division allegedly responsible for the problem) over steep legal bills. The cost of Walmart's FCPA sanctions is likely to be much higher because of this decision.

More will be learned about the facts of the Walmart case when it is inevitably settled in expensive enforcement actions. ${ }^{7}$ Based on currently available information, however, it has not been established that any senior Walmart manager in the United States knew of the bribery while it was going on. There is serious senior management responsibility for what happened at Walmart - both in terms of the incentives and controls in Mexico and in terms of the company's initial response to allegations of criminality. But that responsibility is unlikely to lead to individual criminal liability, for bribery or perhaps even obstruction of justice.

\section{The Role of Criminal Law}

Before considering the law's alternatives when it comes to criminal sanctions, one should ask whether criminal sanctions are even necessary. Perhaps private arrangements, encouraged by legal regulation, could better control the relationship between corporate management and corporate crime. American law also has large and vibrant institutions of civil sanctioning, both private and public, and those institutions are as theoretically open to normative analysis and reform as institutions of criminal sanctioning.

\subsection{PRIVATE SANCTIONING}

Many non-legal incentives influence the corporate agent in decisions about whether to engage in behaviors that violate the law. Chief among these are the hiring, compensation, and promotion programs of a particular firm, which can vary widely and are subject to relatively little legal control (Arlen and Kraakman 1997; Efendi et al. 2007). (At least not substantively; disclosure regimes are extensive.)

Another group of important influences are temporal. When an actor knows herself to be in a last period of employment, or that her firm may be in a final period of solvency, her incentives can change dramatically (Arlen and Carney 1992). Reputational incentives can also be important, and may push in the other direction, if a corporate actor expects to have a prolonged career in her profession or industry. Perhaps these non-legal forces can be manipulated through legal

\footnotetext{
${ }^{7}$ The case has been somewhat opaque since the release of an initial, extremely detailed media report (Barstow 2012). See Aruna Viswanatha and Devlin Barrett, Wal-Mart Bribery Probe Finds Few Signs of Major Misconduct in Mexico, WALL ST. J., Oct. 19, 2015.
} 
policy, as many observers have discussed with respect to the banking industry in the wake of the 2008 crisis.

Just as one can debate how to structure the financial and career incentives of managers to counteract the potentially damaging agency costs of "short termism," one could discuss how to arrange those incentives to reward efforts to prevent corporate crime. Available tools, which could be encouraged as a matter of good corporate governance or mandated by legal regimes, include restricted stock (or bonuses) that would vest (or be paid) only after a specified tenure of "clean" (crime-free) management; provisions for clawing back compensation in the event of corporate crime; and even abandonment of equity compensation altogether. Indeed, some legal regimes are moving in this direction. ${ }^{8}$

The details of such programs are devilish, as they are in general on the question of the optimal structure of compensation for executives of large public firms, a question that has hardly produced consensus in an extensive recent literature. (Bhagat et al. 2014). Unanticipated and perverse consequences are always a problem in such design projects. Indeed, consider all that has happened with option compensation itself.

Among other problems, this type of program would import into the arena of compensation design many of the same difficulties that confront the design and enforcement of regimes of corporate criminal liability themselves. The challenge is more than getting to a compensation system that eliminates or dampens the agency cost problem in corporate crime. It is also defining what instances of corporate crime are in fact the product of agency costs and thus the ones that ought to implicate management's compensation. That is, shifting the point of intervention from liability to compensation does not avoid the challenge of determining when the instrument should apply. Moreover, compensation penalties could perversely enhance managerial incentives not to report or to cover up corporate crime (Arlen 1994).

There is also a problem of theory. This problem is implicated in the general problem of corporate criminal liability but it arises more directly and problematically in the design of management compensation. The problem of crime by corporations is not just a problem of agency costs between owners and managers (and employees) of large firms. It is also, maybe even principally, a problem of externalities (Schwartz 2015). The non-investing public has at least as big a stake in the regulation of corporate crime as the investing public, especially when it comes to the big cases - the ones involving reverberating harms caused by banks, oil companies, automobile manufacturers, and other large industrial firms. But, the lessons of 2008 and other systemic crises notwithstanding, the

\footnotetext{
${ }^{8}$ See Hamid Mehran \& Joseph Tracy, Deferred Cash Compensation: Enhancing Stability in the Financial Services Industry, Fed. Res. BAnK OF N.Y. ECON. Policy Rev., Aug. 2016; Bank of England, News Release, Prudential Regulation Authority and Financial Conduct Authority Announce New Rules on Remuneration, June 23, 2015.
} 
non-investing public does not have as big a stake in the design of executive compensation as do firms' investors. Put differently, managerial short termism with respect to the financial performance of the firm is not the same problem as managerial short termism with respect to the social costs of corporate crime.

A deeper literature, both positive and normative, on the relationship between management compensation and corporate crime would certainly be welcome. There is much work to do before it will be known whether compensation is a more promising instrument for deterring corporate crime, and specifically for addressing the relationship between firm managers and crimes committed by the firm's employees, than the status quo arrangements of American law.

\subsection{CIVIL SANCTIONING}

Two observations would seem to make civil sanctioning an attractive response to the type of corporate malfeasance that concerns this chapter. First, American law places well known heightened constraints on criminal sanctioning, in both its rules of substantive criminal liability and its regime of criminal procedure. Enforcers thus can levy civil sanctions on corporate managers more easily than criminal ones. Second, corporations cannot be imprisoned. Civil sanctioning regimes thus could sanction corporations just as well as criminal prosecution (Khanna 1996). Oddly, though perhaps not illogically, these two observations add up to the claim that when it comes to corporate crime the difficulties of criminal sanctions should be avoided altogether because such sanctions are both exceptional and not really that special at all.

In the theoretical argument over corporate criminal liability, comparative arguments about civil and criminal sanctioning for corporations have been the heart of the contest (Fishel and Sykes 1996, Khanna 1996). To repeat, this chapter does not seek to settle that enduring debate. Indeed, it is not likely an argument that can be won with the tools of theory. Its final resolution depends on empirical questions that could not be answered except through grandiose counterfactual experimentation.

On paper, one can design all manner of civil sanctioning regimes, applicable to both individual corporate managers and firms, that might achieve the optimal deterrence of corporate crime. One can even imagine a world in which Congress enacted a theoretically optimal set of regimes, perhaps abetted by new administrative enforcement structures. One cannot know without trying, however, whether such a regime would perform better than the current mix of civil and criminal liability, or any other mix that does include some form of corporate criminal liability.

Much of this uncertainty is because the effects of criminal sanctions include components that are difficult to specify in theoretical models or measure in empirical analysis. Most would agree as a matter of positive fact that criminal 
sanctioning includes a stigmatic (or expressive or normative or reputational) effect that civil sanctioning cannot fully replicate. That effect has a lot to do with social meaning (Buell 2006, Kahan 1997). Therefore, it is highly contingent on particular social and legal arrangements. Theory can suggest a lot, including even arrangements in which criminal sanctioning no longer has such special effects and civil sanctioning has more communicative potency. At that point, "criminal" and "civil" would no longer mean what they now do and the discussion is left on dry ground that does not seem a useful place from which to think about problems like BP, GM, JP Morgan, and Walmart.

The argument over civil versus criminal sanctioning can be somewhat advanced with what is known about present legal institutions. As for individual corporate managers, at least two forces that appear difficult to dislodge constrain the influence of civil sanctions. First is the basic structure of American corporate law, which not only allows but welcomes indemnification, advancement, and compensation of managers for sanctions, attorneys' fees, and other expected costs of liability for conduct on the job (Baker and Griffith 2010, Buell 2007). Not only does law bless these arrangements, the market for corporate talent makes them the norm. ${ }^{9}$ On top of this, corporate law has ensconced the business judgment rule, a special substantive doctrine of deference that, where it applies, places a legal buffer around the decisions of corporate managers. ${ }^{10}$

It is believed that that the economy is better off when the most talented managers can be persuaded to take legally risky jobs, and to take risks while doing those jobs, without excessive fear of personal ruin. Legal analysis in this area can be criticized for sometimes speaking out of both sides of the mouth: "Hit those managers hard in their own pockets, that will deter all this corporate malfeasance. But don't scare away the talent lest we squelch innovation and job creation."11

A second force limiting civil sanctioning of individual managers is asset insufficiency. In the language of economic analysis, the corporate manager will often turn out to be insolvent in relation to the optimal sanction. According to the Beckerian model, the less likely is detection of crime-by consensus a special problem in the corporate context - the higher the sanction must be set in the cases that are prosecuted (Becker 1968).

The problem is worse than that, ex post the corporate crisis, managers might have pockets too shallow for a big enough fine. (Think of Enron's Ken Lay or

\footnotetext{
${ }^{9}$ There are limits to indemnification for monetary sanctions imposed for criminal or bad faith conduct, and imprisonment of course cannot be indemnified against. But advancement of expenses in defending against such charges is allowable and routine, and claw-back of advanced expenses following liability has been sporadic at best.

${ }^{10}$ See In re Walt Disney Co. Derivative Litig., 906 A.2d 27 (Del. 2006).

${ }^{11}$ This sort of ambivalence about the capitalist project pervades the project of managing corporate wrongdoing and is the organizing theme of this author's book-length treatment of corporate crime (Buell 2016).
} 
Worldcom's Bernard Ebbers, who levered everything they had on their equity holdings in their own companies.) It is that the wealth that managers have accumulated might largely have come from the troubled corporate venture itself, whether or not that wealth represents proceeds of actual crimes. They may have substantial funds in their own pockets but those funds can consist of recent compensation rather than a wealth stake accumulated while working for years by the sweat of the brow.

Civil sanctions would have to make it so the game of potentially lucrative misconduct is not worth the candle for senior managers. But if the firm doles out the candles to the players just for sitting down at the table, there is little reason not to play - even if the player perceives a high risk that both the game and the candle will be lost. While shareholders, at least in theory, do not want managers to engage in legal misconduct, shareholders do want managers to engage in some level of risk-taking. American markets and law not only allow but encourage open, welcoming tables and robust incentives for corporate players to play the game, including the riskiest versions of the game in which aggressive players can go all in, that is, bet the firm.

Moving from the individual to the firm, the two most important observations about current sanctioning institutions have to do with criminal liability, not civil. First, criminal liability imposes, and therefore threatens, a reputational consequence on firms that civil liability cannot replicate under current conditions. Reputational sanctions are hard to measure fully and their sources are multiple and complex (Arlen and Alexander 2017, Karpoff et al. 2008, Karpoff and Lott 1994). It is not fully clear how the criminal legal process interacts with other factors such as publicity and the nature of a firm's industry to produce the reputational sanction. But that sanction is real, it can be an existential threat to at least some types of firms, and whatever reputational effects civil lawsuits or enforcement actions might have are not as strong.

Second, present institutional arrangements mean that criminal sanctioning communicates more strongly and differently than civil sanctioning, and can have greater material consequences to firms - which, of course, feeds back to the reputational effects of corporate criminal liability. Procedurally, criminal cases must meet a much higher burden of proof and must achieve jury unanimity. Substantively, criminal statutes usually (though not always) require that the government's proof meet a higher fault standard (mens rea or scienter) than civil statutes.

Of course, the Justice Department and corporations rarely go to trial in these cases. And at least some in the corporate sector would argue that prosecutors do not always adhere to the Department's policy of declining to charge or threaten a criminal case unless it is strong enough to produce a guilty verdict. ${ }^{12}$ If this is

\footnotetext{
${ }^{12}$ U.S. Dep’t of Justice, U.S. Attorney’s Manual § 9-27.220.
} 
true, prosecutors may risk losing some of corporate criminal sanctioning's special communicative force. For now, that does not appear to have happened.

Two other institutional features of the criminal process set corporate criminal liability apart from civil (Khanna 1996). The ability to charge corporations for criminal violations creates the power to investigate those violations, which brings in an array of investigative tools, most importantly the grand jury, that are not available to civil enforcement agencies. Under present federal law, criminal convictions of corporations raise the specter of debarment and de-licensing rules that are spread (in disorganized fashion, alas) through the federal regulatory regimes that govern many industries. For many firms, this increases the existential threat of corporate criminal liability and supplies prosecutors with additional sanctioning leverage not present in civil enforcement.

To continue further down this line would risk rehearsing the full theory debate over corporate criminal liability, the bracketing of which has been sincerely promised. Enough has been said to justify what follows: A closer look at precisely how, given the limitations of present legal institutions, criminal law might best address the problem of criminally bad management.

\section{The Role of Individual Criminal Liability}

When it comes to the most costly, systemic lapses in large firms, an effective program for deterring corporate crime should cause senior personnel to fear personal consequences for failures of management responsibility. This is a hard task for criminal law.

The corpus of Anglo-American criminal law includes crimes and expansive theories of liability — such as conspiracy and accomplice liability, and their more elaborate modern follow-ons such as RICO (racketeering) - that deal with problems of group wrongdoing. But these doctrines reject, at their philosophical cores, the idea of punishing individuals for failing to prevent the wrongs of others. As scholars of corporate criminal liability have observed, ancient rules for punishing individuals purely vicariously, such as Medieval law's "frankpledge," have been discarded in the common law's dustbin (Alschuler 2009).

\subsection{THE ROLE OF MANAGEMENT IN CORPORATE CRIME}

The most common observations about the limitations of criminal prosecutions with respect to senior corporate managers are that cases are hard to win and there have not been enough of them to make a difference (Partnoy 2011). Criminal enforcement's deficits are said to include, among others, thorny problems of detection and evidence discovery in the policing of white collar crimes, high hurdles to proof in criminal proceedings, and reliable features of individual psychology in the business context that work against law's deterrent message (Buell 2014). 
But consider again the relationships between the senior managers of BP, GM, JP Morgan, and Walmart and the wrongs described earlier in this chapter: the deaths and oil slicks, the car crashes, the accounting fraud, and the bribery. Individual criminal sanctions suffer from a more fundamental limitation in deterring corporate crime. Oftentimes, such sanctions are not directed to the source from which individual wrongdoing springs. Even successfully punishing individual violators does not deter the management behaviors that must be discouraged in order to prevent corporate crime over the long haul. And punishing managers faces higher barriers than the practical difficulties of criminal enforcement. It runs into the basic architecture of criminal law.

\subsection{THE PROBLEM OF MENS REA}

Take a few of the categories of criminal violation most commonly charged in investigations of major corporate crime: fraud, bribery, lying in communications to the government (and thus often to the public), and polluting public lands, waters, and airways. The federal criminal code infamously deals with these forms of wrongdoing through dozens, if not hundreds, of statutes and regulations, many of them nauseatingly complex (Beale 1994). But most statutes that can lead to serious prison time share common forms of threshold that have to do with individual mental state, and sometimes also with scale of the harm.

Imposing criminal liability for fraud requires proof that the defendant had the specific intent to defraud, meaning that she set about her conduct knowing and desiring that it would deceive another person in a way that could lead that person to part with property or another important interest (Buell 2011). In cases of fraud by affirmative misrepresentation, this requirement generally includes that the defendant knew she was uttering falsehood. (Some federal cases have suggested recklessness as to falsity might be sufficient for criminal liability, though this is controversial.) In cases of fraud by omission or nondisclosure, this requirement generally means that the defendant thought about her obligation to make disclosure and decided to disregard that duty in order to deceive the victim.

Criminal liability for bribery, including under the Foreign Corrupt Practices Act, depends not just on proof of a quid pro quo (a contract-like understanding) between the briber and bribed official (or at least an attempt by the briber to create one) but also on the defendant having acted with a "corrupt" state of mind, meaning the purpose of inducing the official to violate legal obligations. ${ }^{13}$

Laws that police honesty in dealings with the government usually authorize criminal sanctions only upon proof that an individual knew of the falsity of, for example, a regulatory filing. ${ }^{14}$ A good example are the so-called Sarbanes-Oxley certification requirements, statutes sometimes said to be a strong tool against

\footnotetext{
${ }^{13} 18$ U.S.C. $\S \S 201,666$; United States v. Bonito, 57 F.3d 167 (2d Cir. 1995).

${ }^{14} 18$ U.S.C. § 1001; United States v. Hsia, 176 F.3d 517 (D.C. Cir. 1999).
} 
corporate managers because they require senior officials to personally certify the accuracy of financial statements on pain of criminal punishment. ${ }^{15}$ Criminal violations of these statutes require proof that the signer knew that the financial statements were false; reliance on accountants, lawyers, and other delegates of responsibility is as much a defense under these laws as it has always been in cases of financial reporting fraud.

Tax prosecutions include a general mistake-of-law defense, under Supreme Court rulings that the requirement that the defendant have acted "willfully" in the criminal tax statutes means he must have acted with knowledge of illegality. ${ }^{16}$ Securities regulations include a provision that provides a kind of mistake-of-law defense for violating the SEC's filing requirements if the defendant can prove he lacked knowledge of the relevant rule. ${ }^{17}$ Money laundering liability requires proof that the defendant knew the funds he helped bank or otherwise transact derived from criminal activity. ${ }^{18}$ Felony liability for violating the Clean Water Act requires proof of actual knowledge that a discharge is unauthorized or exceeds a permit. ${ }^{19}$ Felony liability for misbranding pharmaceuticals (that is, illegally marketing them for off-label use) requires proof of intent to defraud. ${ }^{20}$ All of these mens rea requirements are subject, of course, to the general constitutional mandate of proof beyond a reasonable doubt. ${ }^{21}$

For crimes based on knowledge rather than forms of specific intent (to defraud, to obstruct justice, and the like), the doctrine of willful blindness might appear to ease the path to conviction. But the federal courts have been at pains to prevent this doctrine from being treated as anything less than a genuine, and justifiable, substitute for knowledge. ${ }^{22}$

Willful blindness is not recklessness. A defendant's awareness of some risk of falsity or some risk that banked funds are derived from crime, for example, will not suffice. A defendant must both know of a substantial risk that the operative fact exists and take affirmative step to avoid acquiring additional knowledge. Red flags thus are not sufficient to establish willful blindness. Chronic inattention, as opposed to affirmative suppression of information, also will not suffice. Courts seek a basis for concluding that the defendant all but knew, such as a directive to others not to inform the defendant or an otherwise inexplicable failure to act in response to information. ${ }^{23}$

\footnotetext{
1518 U.S.C. $\S 1350$.

${ }^{16}$ Cheek v. United States, 498 U.S. 192 (1991).

${ }^{17} 15$ U.S.C. $\$ 78 \mathrm{ff}(\mathrm{a})$.

1818 U.S.C. $\$ \S 1956,1957$.

${ }^{19} 33$ U.S.C. $\S 1319(\mathrm{c})(2)$.

2021 U.S.C. $\$ 333(\mathrm{a})(2)$.

${ }^{21}$ In re Winship, 397 U.S. 358 (1970).

${ }^{22}$ Global-Tech Appliances, Inc. v. SEB S.A., 563 U.S. 754 (2011); United States v. Salinas, 763 F.3d 869 (7th Cir 2014).

${ }^{23}$ Although it didn't matter because the proof of actual knowledge was overwhelming, the Second Circuit may have pushed the envelope a bit in approving the use of a willful blindness argument in
} 
The mens rea demands of substantive criminal law mean two things for the large cases of corporate crime that concern this chapter. First, provable, and thus punishable, criminal violators will tend to occupy lower rungs on the corporate ladder. There will be the occasional case like Enron or Worldcom in which a conspiracy to commit accounting fraud, for example, extends fully into the inner management suite. But in most cases individuals close enough to execution of the product or transaction to know enough for criminal liability will not be the senior managers (and certainly not the board members) who bear responsibility for designing and implementing systems for the prevention of crime.

Second, senior managers will know-whether they admit to liking it or notthat they enjoy insulation from punishment for the vast majority of criminal violations that might occur within their firms, even as they may benefit from the enhanced corporate income or reduced costs such crimes produce. Indeed, the effect of criminal law is at least partially perverse: The demands of proof of mens rea for individual criminal liability provide an incentive for managers to shield themselves from what is going on, possibly reducing corporate efforts to prevent crime. A compulsion to golf is bad corporate management but good criminal defense. (The point about a perverse incentive not to monitor, of course, has also been made with respect to corporate criminal liability (Arlen 1994).)

American criminal law is far from naïve about the problem of individuals who shield themselves from liability for the crimes of underlings. Long experience with organized crime, international narcotics trafficking, terrorism, and other problems has produced flexible and powerful statutes and doctrine such as conspiracy law, RICO, and broad anti-terrorism laws. But BP's Tony Hayward is not Tony Soprano. The nonfictional likes of Soprano have been convicted under conspiracy laws and their analogues without proof of direct involvement in substantive offenses because their businesses are thoroughly, completely criminal. Proof of "association," "involvement," and the like is itself proof, at least in part, of criminality.

This proof dynamic is unavailable in cases of corporate crime. Senior managers of even the most broken corporations spend most of their time on legitimate activities that have been licensed, indeed warmly welcomed, by state and federal governments. No defendant would attempt, at a criminal trial, to disprove the existence of British Petroleum as one might dispute the existence of La Cosa Nostra. Calls to "use RICO against the big banks" and like firms are tiresome given that RICO, while a powerful device for dealing with problems like joinder and statute of limitations, in no way displaces the requirement that underlying criminal violations be proved. ${ }^{24}$ Labeling Lehman Brothers a "RICO

the prosecution of Worldcom's Bernard Ebbers on the ground, the court said, that there was evidence that Ebbers threw reports in the trash without reading them. United States v. Ebbers, 458 F.3d 110 (2d Cir. 2006).

${ }^{24} 18$ U.S.C. $\S \S 1961$ to 1963. 
enterprise" would not have been a way of bootstrapping individual criminal violations by mid and lower-level employees into crimes by management personnel.

\subsection{THE PROBLEM OF ACTUS REUS}

Generally speaking, American law rejects criminal liability for omissions. Failure to rescue, failure to aid, and (most aptly here) failure to prevent another from committing a crime (or even failing to help the police catch a violator) do not give rise to criminal liability. Whatever morality mandates, our legal obligations to each other do not generally require us to do these things (LaFave 2010).

The matter of duties to render aid is, of course, subject to lively normative debate. But positive law sides with familiar arguments against such criminal liability, ranging from American commitments to individual liberty and choice, to worries about incentives that might cause people to do more harm than good, to deep problems of line-drawing in specifying conditions under which law might obligate affirmative action (Dressler 2012).

Exceptions to this principle are constructed around duty, which is certainly a familiar concept in the legal regulation of corporate managers. But "duty" is of course an empty concept standing alone: One has a legal duty to do what law imposes a duty to do.

In criminal law, the duties that courts and legislators have found to give rise to an obligation to act, at pain of criminal liability for omissions, are those that inhere in special relationships such as parent-child, spouse-spouse, doctor-patient, or teacher-student. The duty question most often arises with so-called result crimes, in which the issue is the duty of the omitting person (such as the parent) to have acted to prevent a harmful result (such as death) that befell the victim (such as the child). A sadly repeating fact pattern is the obtuse or abusive parent prosecuted for failing to obtain medical help for a child who was gravely ill or injured and ultimately died. ${ }^{25}$

Drafters of criminal laws have the option of sweeping within those duty relationships that give rise to a general theory of omission liability the relationship between a corporation's managers and its owners. (I assume the relevant duty would not run between managers and the public at large, for that would be a capacious duty without analogue in existing law.) The argument perhaps would hold that a corporate manager can be criminally liable for omitting to prevent the crime of a corporate employee because she has a duty to prevent harm to the corporation and crime (or this crime) harms the corporation.

${ }^{25}$ E.g., State v. Norman, 808 P.2d 1159 (Wash. Ct. App. 1991). 
This sort of move would strain the basic structure of American criminal law, not to mention corporate law. It is difficult to think of any analogue to this form of duty in the relationships that criminal law has recognized as giving rise to omission liability. These relationships generally are close, one-to-one, and such that the bearer of the duty is positioned highly proximate to the harm. Given the role occupied by the duty bearer and her capacity to respond and intervene (the parent being the paradigm case), the instrumental and deontological cases for punishing the failure to act are persuasive. Criminal law's restrictions on the categories and scopes of these duties ensure that the omission cases that are prosecuted tend to be normatively compelling.

For example, criminal law might impose liability on a school nurse who kept a drug-overdosing student "resting" in the infirmary instead of calling for an ambulance if the student then had a seizure and died for lack of speedy hospitalization. However, criminal law would not likely impose liability on the nurse who sat in his office while a deadly virus spread undetected in the cafeteria because he had failed to distribute hand sanitizer throughout the building.

Some of the difference between these two cases has to do with the degree and form of the actor's recklessness or negligence. But a lot has to do with how the duties are conceived-conceptions that implicitly include considerations of the causal relationship between the bearer of the duty and the harmful result. In the sort of corporate cases relevant here, the senior manager is much more like the second nurse than the first.

A requirement that the corporate manager act based on a duty extending to all corporate affairs would also dismantle barriers between corporate and criminal law. This is a familiar worry from the long legal contest over the use of an "honest services" theory under the federal mail and wire fraud statutes to prosecute corporate officials for breaches of loyalty to corporate owners. That struggle concluded with the Supreme Court rejecting the idea of criminal fraud based solely on a duty breach, requiring prosecutors to prove that such a miscreant corporate official also received a bribe or a kickback. ${ }^{26}$ It would be an even greater threat to regimes of corporate regulation to bootstrap a general duty of managers to prevent corporate crime - a Caremark duty, that is - into a form of criminal liability. ${ }^{27}$

One might complain that the phenomenon of criminally bad management is not really a matter of omissions to act at all. If one adjusts the time frame in these cases, one can make the manager's failure to intervene and prevent crime a form of affirmative participation (Kelman 1981). When managers of GM pushed aggressive cost cutting through the company, their acts provided incentives for

\footnotetext{
${ }^{26}$ See Skilling v. United States, 561 U.S. 358 (2010); see also id. at 415 (Scalia, J., concurring).

${ }^{27}$ In re Caremark Int'1 Inc. Derivative Litig., 698 A.2d 959 (Del. Ct. Chancery 1996); see also Assaf Hamdani \& Reinier Kraakman, Rewarding Outside Directors, 105 MICH. L. ReV. 1677 (2007)
} 
employees deeper within the firm to take steps that caused the ignition switch failures. When managers of BP implemented a strategy of going for riskier offshore deposits, they caused the Deep Horizon well to blow up. When JP Morgan's managers set their compensation and monitoring programs for their derivatives traders, they caused the traders to deliberately mismark the books. When Walmart's global managers pushed fast into Mexico, they caused managers there to use bribery to get stores built.

Moving the time frame in this way, though, only runs the problem into the other pillar of criminal law, that is, mens rea. Put another way, concurrence of the elements is a requirement in analysis of criminal liability. The further back one moves in time to locate the actus reus, the weaker the argument is for the relationship between any mens rea at that point in time and later events for which one might argue responsibility should be imposed.

And moving the time frame requires playing another game of stretching in criminal law, one much like stretching time frames: the game of levels of abstraction. This is a recurring problem in cases of negligence or recklessness. The relevant criminal event now has to be some well accident, some auto engineering failure, some financial misreporting, or some bribery-not the actual violations in the case.

The existing contours of criminal law either cannot accommodate individual liability for criminally bad management, or they can do so only with strained and questionable arguments. One turns, then, to the question of how individual criminal liability might be reshaped to address criminally bad management.

\subsection{STRICT LIABILITY AND PATHS FOR REFORM}

Law could reject, or at least migrate away from, the basic architecture just described. It could impose punishment for forms of management misconduct, or undesirable behavior, not previously subject to serious criminal liability. These days, any such expansionist move raises hackles because of the American criminal justice system's bad reputation for overcriminalization in substantive law and overincarceration in the enforcement of law. But the option nonetheless should be examined.

One direction for reform would be to dispense with mens rea requirements and impose liability solely on a manager's relationship of supervision or responsibility toward the part of a corporation's operations in which wrongdoing occurs. There are, of course, already lots of strict liability offenses in federal white collar criminal law. Industry groups and overcriminalization critics have long lamented this (Walsh and Joslyn 2010). 
Some federal statutes do impose liability for particular non-actions (omissions). It can be a crime, for example, to fail to file one's taxes ${ }^{28}$ or to fail to maintain adequate systems of accounting controls. ${ }^{29}$ With these offenses, there is no need to wade into murky questions of general duties. If there is something the law really wants corporate managers to do, a statute can simply say what that is and that criminal penalties may be imposed for failing to do it.

This is what the "responsible corporate officer" doctrine does. It is a form of liability imposed by a limited number of federal statutes (Henning 2014, Sepinwall 2014). These rules are often described as something like "strict liability for CEOs." But they are more than that. They are strict liability for omissions to act. And it is the omission part (the lack of affirmative actus reus), not the strict liability part (the lack of mens rea) that really make the responsible corporate officer doctrine American criminal law's closest thing to a crime of criminally bad management.

John Park of the famous United States v. Park ${ }^{30}$ was President of Philadelphia-based Acme Markets, Inc., a company the FDA caught with rat droppings in its Baltimore warehouse. Park was held criminally liable because he failed to do enough about sanitation in his company's facilities when that matter was within his responsibilities as head of the company. Indeed, while his liability was technically strict under the statute, Park himself had some mens rea: The FDA had warned the company in writing about the problem in its warehouses and Park saw the FDA's letter.

The responsible corporate officer doctrine probably gets more attention in law schools and legal commentary than it deserves. There is no general such "doctrine" in federal law. It can arise only by statute. Instances in which I am aware of Congress imposing this form of liability are in the Food Drug and Cosmetic Act (FDCA), for responsible managers failing to prevent the misbranding or adulteration of statutorily covered products, ${ }^{31}$ and in the Clean Water and Clean Air Acts, for responsible managers failing to prevent covered discharges without, or in violation of, permits. ${ }^{32}$ Both of these statutes impose misdemeanor liability only.

The closest thing to these offenses in securities law is the "books and records" provision of the Securities Exchange Act of 1934, which can be violated by the mere failure to maintain adequate systems of accounting controls. ${ }^{33}$ The securities prohibition, however broad, does not impose strict criminal liability: a criminal case requires proof that the defendant "willfully" violated the record-

\footnotetext{
${ }^{28} 26$ U.S.C. $\$ 7203$.

${ }^{29} 15$ U.S.C. $\S \S 78 \mathrm{~m}, 78 \mathrm{ff}$.

${ }^{30} 421$ U.S. 658 (1975).

${ }^{31} 21$ U.S.C. $§ 331$ (as interpreted in United States v. Dotterweich, 320 U.S. 277 (1943)).

3233 U.S.C. $\$ 1319(\mathrm{c})(6)$.

${ }^{33} 15$ U.S.C. $\$ 78 \mathrm{~m}$.
} 
keeping requirements. ${ }^{34}$ Regulatory crimes such as these, which the Supreme Court has sometimes referred to as "public welfare offenses,",35 are not often implicated in the big corporate scandals involving fraud, bribery, safety, and pollution.

If this style of criminal offense were expanded into the realm of serious felony punishment, two constitutional challenges would be likely. First, a statute would have to describe the "it" that the corporate manager could be punished for omitting to do, with sufficient specificity to defeat constitutional notice objections. "Manage well at pain of imprisonment" might not be a constitutionally acceptable rule. Second, if the Supreme Court had occasion to review the question of what scope of strict liability Congress intended to impose on corporate managers for failure to act, it might not hold to the expansiveness of the Park decision.

Concededly, the only case in which the Court has rejected criminal omission liability on due process grounds is the famous and dated case of Lambert $v$. California ${ }^{36}$ in which Los Angeles attempted to criminalize the act of being in the city by convicted felons who had failed to register with city hall. The problem in Lambert was the combination of omission liability with unfair surprise about the content of law. If Congress wanted to make it a crime for the CEO or CFO of a public corporation to fail to prevent securities fraud by the company's employees, maybe it could do so. But probably only within reason, and maybe not beyond misdemeanor liability.

In any event, the ultimate issue is normative. Should American law impose criminal omission liability on corporate managers for failure to prevent fraud, bribery, environmental offenses, and the like? Overdeterrence would be the obvious and fairly massive worry. If we really wanted to deter managers from allowing or failing to prevent corporate crime, we could take the China approach: the death penalty for tainted milk. (Assuming that the defendants in that example did not taint the milk themselves, directly or indirectly.) Deterrence arguments, carried to the extreme, can be used to justify punishing even wholly innocent persons.

Responsible corporate officer liability under the FDCA and CWA does not seem to have shut down pharma or the sewage treatment industry, nor has it destroyed the market for executives in those sectors. Would imposing such liability for fraud in the banking industry, for example, decimate entrepreneurship in finance and scare competent managers away from such jobs? It is clear what the Chamber of Commerce would say. But it is hard to know.

\footnotetext{
${ }^{34} 15$ U.S.C. $\S 78 \mathrm{ff}$.

${ }^{35}$ E.g., United States v. Balint, 258 U.S. 250 (1922).

36 U.S. 225 (1957).
} 
The more compelling objection to this kind of legislative program is a prior one. It likely would lead to punishment of those who do not deserve it. As is the habit in the American criminal justice system, especially the federal one, prosecutors could be relied on to charge only managers whose nonfeasance was truly appalling. ${ }^{37}$ But that is not guaranteed to be the outcome.

A corporate manager, one might fairly contend, simply does not deserve imprisonment sanctions for failing to prevent a fraud of which she was not aware. (If she was aware, then she is likely liable for conspiring or aiding and abetting.) This is not a controversial assertion. It will not become one until the American social and economic order experiences changes that have nothing to do with criminal law - that is, a fundamental re-conception of the role of the for-profit corporation in society and the moral obligations that those who control it have to the rest of us. ${ }^{38}$

To be sure, the sort of criminally bad management under discussion here can fall between full-blown, conventional group criminal liability and strict liability for failure to prevent crime. A responsible manager might have known enough to be seriously at fault in what happened but not enough to have been an accomplice or conspirator in the specific criminal violation.

So what might be accomplished through new crimes of recklessness or negligence? Consider, for example, what England has recently done. Parliament has enacted a criminal offense, punishable by up to seven years in prison, of what might be called (though English law does not call it this) reckless bankruptcy of a bank. ${ }^{39}$ The elements of this crime are the following: (1) that the defendant was a senior manager of a financial institution (these are defined terms), (2) that the defendant participated in a decision or failed to take steps to prevent a decision, (3) which decision caused the failure of the financial institution, (4) the defendant was aware at the time of the decision that implementing the decision risked the failure of the institution, and (5) the defendant's "conduct in relation to the taking of the decision [fell] far below what could reasonably be expected of a person in [the defendant's] position."

\footnotetext{
${ }^{37}$ For example, in a notable recent prosecution the government deployed the responsible corporate officer doctrine to obtain three-month prison sentences for managers of an egg business that shipped products with salmonella, sickening purchasers. The government's proof included abundant, though legally unnecessary, evidence of the defendants' negligence. United States v. DeCoster, 828 F.3d 626 (8th Cir. 2016). Indeed, one appellate judge concurred in affirming the prison sentences, he said, only because of the presence of the negligence evidence.

${ }^{38}$ Morally, corporate responsibility does not approximate military command responsibility. In the context of warfare, law and norms justify holding the supervisor responsible for the crimes of subordinates because the supervisor must train, and order, subordinates to surrender their moral agency, including the agency not to kill other humans. Even in that context, the imposition of criminal liability on commanders without requiring some degree of subjective mens rea is controversial (Martinez 2007).

${ }^{39}$ UNITED KINGDOM FINANCIAL SERVICES ACT 2013 § 36.
} 
This criminal statute has no close analogue in American white collar criminal law, though some have argued in the wake of the banking crisis that prosecutors in the United States should have pursued criminal prosecutions of bank managers for recklessness, or at least that Congress should have legislated to authorize such prosecutions (Partnoy 2011, Eisinger 2014, Taibbi 2014). There are ironies here. American criminal law has clung to some harsh ideas like felony murder and capital punishment that English criminal law has jettisoned. And some may recall that after the wave of criminal and civil corporate enforcement in the United States following the collapse of Enron in the early 2000s, a common cry of alarm in New York and Washington was that capital was fleeing offshore to the safer regulatory haven of London. Perhaps London now looks legally scarier for corporate managers.

Recklessness is, of course, a less controversial basis for criminal liability in the United States than negligence. Recklessly caused deaths are routinely treated as serious criminal homicides ("involuntary manslaughter") and recklessness can be found in statutes defining other serious offenses, such as forms of assault and arson. $^{40}$

In the corporate context, keep two points about recklessness in mind. First, recklessness in criminal law is not gross or especially serious negligence. Being really careless is not being reckless. Recklessness is a knowledge state, specifically awareness of risk. ${ }^{41}$ The reckless individual must consciously advert to the question of risk and decide to press forward. That is the form of thinking that makes recklessness sufficiently blameworthy to warrant criminal punishment, at least when bad things happen after people choose to run risks.

Second, risk in the criminal law is not a vague concept floating in the air. Recklessness offenses require that the actor have consciously disregarded a sufficiently large and serious risk of a particular sort. In other words, the mental state of recklessness is one element of the offense but the result or factual circumstance as to which the actor must be reckless is another and equally important element. ${ }^{42}$ The manslaughter defendant disregards the risk that his conduct (drunk driving, for example) will cause the death of another person. The reckless sexual assaulter disregards the risk that the person with whom he has intercourse has not consented.

There can be no such thing, therefore, as a crime of "reckless corporate management." Such an offense would leave the question of reckless as to what? England's new banking statute does not go this far, but maybe it comes close. While the statute specifies that the defendant must have been aware of a risk that her decision, or the decision she failed to prevent, presented a risk of the financial institution failing, "failure" of a firm encompasses a large array of scenarios. The

${ }^{40}$ E.g., N.Y. PENAL LAW $\S \S 120.01,150.05$.

${ }^{41}$ American Law Institute, Model Penal Code $§ 2.02(2)(\mathrm{c})$.

${ }^{42} I d$. 
statute further defines failure as insolvency but does not say anything about what causes qualify and, of course, does not even attempt to specify what level of probability constitutes risking the firm for purposes of this law.

The English statute therefore comes down to the part of the offense that involves negligence (or perhaps gross negligence), not recklessness: the requirement that the defendant's "conduct in relation to the taking of the decision [fell] far below what could reasonably be expected of a person in [the defendant's] position." But then the law is in the perilous and perhaps undesirable realm of drawing lines, if they even can be drawn, between the lack of due care in management that warrants imprisonment and the carelessness that should draw at most a lawsuit for breach of fiduciary duty. And, of course, there is the serious, though not consensus, argument that a person's negligence never provides sufficient justification for criminal sanctions (Alexander and Ferzan 2009).

There is an even more essential point about criminal liability for recklessness in this context. Managers of corporations are supposed to press forward in the face of risk of failure. Indeed, the mere act of taking the management reigns of a business necessarily requires one to consider and accept the risk of insolvency.

Consider this rhetorical question, which might seem trenchant (especially for the GM case): "American law imposes felony liability on reckless automobile drivers who kill, so why would it be any real departure to impose felony liability on senior managers who manage (drive) corporations in a way that kills people?" The analogy fails because assessment of risk is completely different in the two cases. Except perhaps in a case of serious exigency, there is no social value in risky driving. There is social value in risky corporate managing, where the question is whether and how risks are weighed, not whether they should be taken in the first place.

Or think about it this way. As Ken Simons has explained, risk analysis in the criminal law of recklessness and negligence includes a mostly hidden dimension of specificity versus generality or, if you like, known identity of the victim or harm (Simons 2010). To take a hypothetical, Sally, the manager of a massive tunnel construction project, orders that an expensive section be lowered into place immediately, before it breaks at great cost, even though Joe the worker appears trapped beneath it and likely will be crushed. Sally might be guilty not only of reckless homicide but of murder. However, if manager Betty authorizes starting the same tunnel construction project in the first place, knowing that there is a high probability that at least one worker will be killed during the project, she is not likely guilty of any crime at all. The risk-taking manager of a large bank is usually Betty and rarely Sally.

Reform is not out of the question. But it would be a heavy lift. The point here has been to run to ground the severe limitations of American criminal law, as both 
a positive and normative matter, as a tool for imposing individual liability on corporate managers for running firms in ways that enable and fail to discourage criminal violations by employees.

Take the individual prosecution of Donald Blankenship, the CEO and Chairman of Massey Energy, a now notoriously transgressing coal company. ${ }^{43}$ The government alleged that Blankenship "closely managed" (indeed, obsessively micromanaged) the company, that he knew of hundreds of safety violations, that he "had the ability to prevent most of the violations," and that, in a ruthless quest to extract coal profits, he "fostered and participated in an understanding that perpetuated [a] practice of routine safety violations" at a West Virginia mine that eventually experienced a fatal explosion that killed nearly 30 miners. If the government had proved even half of the facts alleged, it would have established a level of personal culpability of Blankenship for disastrous corporate management that far outstrips a case like BP, GM, JP Morgan's London Whale, or Walmart.

Nevertheless, the government secured a conviction of Blankenship only for one misdemeanor count charging a mine safety violation. On the other charges, which included securities fraud, the government was unable to prove beyond a reasonable doubt, among other propositions, that Blankenship knew it was a lie for the company to say that it "does not condone" mine safety violations and strives "to be in compliance with all regulations at all times"; or that Blankenship conspired with others at the company to willfully violate mine safety laws and to obstruct the Mine Safety and Health Administration from enforcing federal law. Blankenship was a micromanager but things still became cloudy at his trial.

Even the most culpable of corporate managers can be hard to convict for what happens on their watches. The fit between basic concepts of individual criminal responsibility, which have remained stable for a long time, and the structure of the large corporate institution, which has changed a great deal over time, is awkward at best.

\section{The Role of Corporate Criminal Liability}

There is a gap when the law comes to management responsibility for corporate crime. Increasing public frustration with corporate crime has produced a demand for law to fill that gap. Politically responsive institutions, chiefly prosecutors' offices, have looked for ways to use existing legal tools to meet that demand. The story of corporate criminal liability's evolution and growth in the American legal system over the last two or three decades can be understood as driven, in important part, by this dynamic between public demand and enforcement institutions.

\footnotetext{
${ }^{43}$ United States v. Blankenship, Crim. No. 5:14-cr-00244 (S.D. W. Va. Nov. 13, 2014) (indictment).
} 
Corporate criminal liability has been serving as a substitute to individual criminal liability. It functions to deter corporate managers from engaging in practices that enable and tolerate employees' criminal violations. Whether this legal tool is optimal or not is unclear and remains hotly debated. Meanwhile, both corporate managers and federal prosecutors act as if they understand corporate criminal liability as filling the gap.

\subsection{MANAGERS AND CORPORATE CRIMINAL LIABILITY}

If one spends time with the corporate defense bar and corporate management-even if one regularly reads the Wall Street Journal and the business pages - one cannot help but appreciate how the prospect of corporate criminal liability is the first, last, and greatest concern of legal risk for corporate managers and their counsel. In most or all major industries, managing the firm to avoid this form of legal sanction is an overriding practical imperative.

When managers think about corporate criminal liability, they do not of course think about the prospect of landing in prison themselves. But they do think about personal consequences. To steer one's company into the roiling waters of indictment and likely conviction is, in many important economic sectors, to have failed almost per se as an executive-with all the consequences that might bring in reduced compensation, shrunken reputation, weaker career prospects, and lost self-esteem. A massive federal investigation followed by admission of widespread misconduct and an onerous settlement can be harmful to an executive resume.

Many of corporate criminal liability's costs, to firms and thus indirectly to those in charge, can be measured in lost market capitalization, loss of revenue from clients or customers, and lost income opportunities from temporary or permanent cancellation of licenses and contracts in whole lines of business. Those grave material costs can run as far as liquidation of the firm, the doomsday scenario contemplated in sectors such as professional services, pharmaceutical manufacturing, and (at least until recently) banking.

Personal costs in this scenario can extend beyond those to the firm, at least as a temporal matter. The manager who runs the corporate ship aground on a criminal prosecution may have a hard time, at least in the market for public company executives, getting that signal event off of her resume. And the psychological consequences could be lasting and profound. The committed executive of the large firm has to have the success, much less the survival, of the firm deeply woven into her personal identity.

The corporate management profession would not expend such enormous energy - both in individual cases and in general discussion about regulatory policy - lamenting corporate criminal liability, and fighting its imposition, if this form of sanction did not, from managers' perspective, have a sharp, even deadly, 
bite. Managers are highly motivated to avoid corporate criminal liability. Thus corporate criminal liability has a deterrent effect on managers even when managers face no prospect of individual criminal liability.

The skeptic might respond with two thoughts. First, those who manage America's largest corporations might prefer the risk of an occasional, episodic run-in with the Department of Justice when something goes wrong to comprehensive, aggressive programs of preventative regulation imposed throughout industries. Incessant talk about corporate criminal liability is a way of keeping the discussion about regulating corporate malfeasance in that arena and leaving the impression that corporate criminal liability is a costly, and therefore effective, control on industry. Second, managers might talk up the potency of corporate criminal liability to play into prosecutors' fears that corporate criminal liability can be too strong, imposing bad collateral consequences that include destruction of jobs and other economic value. This kind of talk conditions prosecutors to be more amenable to forms of settlement that forego indictments and trials, and maybe more open to declining prosecution altogether.

If one has closely followed the discussions in this field over the last two decades, it seems implausible that corporate managers secretly like corporate criminal liability and enjoy dealing with the Justice Department. Of course industrial interests exaggerate the problems they face. It used to be said that no major bank could sustain a criminal conviction without having to close its doors; now several of them have pled guilty to antitrust and other violations with only short-term harm to their stock prices. ${ }^{44}$

But the expenses firms incur in managing even potential prosecutions speak to their treatment of corporate criminal liability as a deadly serious matter. Siemens Corporation, for example, spent over $\$ 1$ billion on professional services (primarily law and forensic accounting) to curry favor with the Justice Department and a court when it ultimately resolved its criminal bribery case. ${ }^{45}$ Walmart has by now spent well over $\$ 500$ million in legal fees in a similar effort, with resolution of its case still to come. ${ }^{46}$ There is a reason why the defense practice in the field of government investigations and white collar crime has become such a lucrative mainstay for America's largest corporate law firms: These are treated as bet the company cases; management does not dare slash these legal expenses in the manner that has threatened large law firms' practices in

\footnotetext{
${ }^{44}$ See Plea Agreement, United States v. Credit Suisse AG, No. 1:14-CR-188 (E.D. Va. May 19, 2014); Statement of Facts, United States v. Credit Suisse AG, No. 1:14-CR-188 (E.D. Va. May 19, 2014); Statement of Facts, United States v. BNP Paribas, S.A. (S.D.N.Y. July 9, 2014); Andrew Grossman, John Letzing, \& Devlin Barrett, Credit Suisse Pleads Guilty in Criminal Tax Case: Agrees to Pay \$2.6 Billion to Settle Probe by U.S. Justice Department, WALl ST. J., May 19, 2014; Jessica Silver-Greenberg \& Ben Protess, BNP Paribas Pinned Hopes on Legal Memo, in Vain, N.Y. TIMES, June 3, 2014.

${ }^{45}$ United States v. Siemens Aktiengesellchaft, Crim. No. 1:08-cr-00367 (D.D.C. Dec. 12, 2008) (Department's Sentencing Memorandum).

${ }^{46}$ Wal-Mart Says Bribe Probe Cost $\$ 439$ Million in Two Years, BloomBERG, March 26, 2014.
} 
areas such as corporate finance, products liability litigation, intellectual property, and commercial real estate (Weisselberg and Li 2011).

\subsection{THE DEPARTMENT OF JUSTICE AND CORPORATE CRIMINAL LIABILITY}

If the manager of the large firm does genuinely fear corporate criminal liability, the question is precisely what corporate criminal liability deters managers from doing (or encourages them to do). That question brings in the prosecutors.

The Justice Department also understands corporate criminal liability as a tool for influencing individual manager behavior. The now familiar story of the evolution over the last several decades of what Jennifer Arlen calls the de facto regime of corporate criminal liability does not need repetition, especially for the experienced reader in this field (Arlen 2012). The U.S. Attorney's Manual, the Holder, Thompson et al. memos, the deferred prosecution agreement, the nonprosecution agreement, the corporate compliance program, the corporate monitor, the U.S. Sentencing Guidelines for corporations, and the other institutions of contemporary federal enforcement and corporate criminal defense-these are American corporate criminal liability (Arlen 2012, Garrett 2014).

The essence of de facto corporate criminal liability is this: what the Justice Department wants above all to see when it confronts a case of corporate crimewhether as a reason not to prosecute or as a reason to settle on favorable terms is effective management practices designed to prevent, and certainly not to foster, crime by a firm's employees. As documented most clearly in Brandon Garrett's work, prosecutors are more concerned - at least in the mine run of cases involving FCPA violations, pharma marketing practices, bank money laundering, environmental offenses, and the like-with the organizational dynamics that generate corporate crime than they are with the individuals who execute the criminal acts (Garrett 2014).

Federal prosecutors just might be right. At the least, they have a theory for what they are doing and are not wantonly throwing around all that discretion they enjoy. (This is an at least partial answer to Judge Jed Rakoff's puzzling over the Department's emphasis on corporate over individual liability (Rakoff 2014).) The low level sales manager in the foreign office who pays the bribe is fungible. Prosecuting the likes of her, one might argue, is like prosecuting all the bookies in Brooklyn or Newark and expecting that to make a dent in organized crime. Using corporate criminal liability to effect change in management practices, and perhaps even industry practices, has a better prospect of actually reducing corporate crime, and the widespread harms it can impose on the public, over the longer term. Corporate criminal liability, because of the leverage it affords the government over managers both in terrorem and in the negotiation of settlements (and even in 
the occasional criminal sentencing of a firm), gives prosecutors (and occasionally judges) a tool to effect firm and industry-wide change.

Whether or not the Justice Department is succeeding in delivering on the promise of its theory is a real question, one that is hard to answer empirically. But at least there is a theory. One can see this theory in action at both the front and back ends of cases of corporate criminal liability. Indictment and settlement discussions are dominated by arguing over how much an instance of corporate crime can be attributed to bad management. How high up was the wrongdoing? How pervasive? What kind of compliance program did the firm have? Is the company a recidivist? The terms of settlements are then dominated by measures designed to change management practices to make future violations less likely. ${ }^{47}$

Maybe corporate criminal liability American style has developed-as the voluminous literature has canvassed-by accident, or path dependence, or political economy, or rent seeking by the bar, or another dynamic unconnected to optimal regulatory design. But maybe also Justice Department personnel have figured out, as they have confronted the scale of firms, the economy, and public harms, that the problem of corporate crime is a problem of management. And that individual criminal liability - as lawyers who practice criminal law know better than anyone - is not well suited to addressing the source of the problem. So they have turned to corporate criminal liability as the best available alternative among the legal tools that federal law gives them.

Even when the Justice Department wants to focus on individual responsibility for corporate crime, it cannot help but stress corporate criminal liability. In obvious reaction to public complaint during the Obama Administration that not enough senior corporate officials are in prison, a Deputy Attorney General issued a memorandum to prosecutors in late 2015 that leaned hard, rhetorically at least, on the importance of aggressive prosecution of individuals. ${ }^{48}$ The memo itself, which described six purportedly new initiatives, only restated the basic theory of the Justice Department's longstanding program in corporate crime: Use corporate criminal liability as the means to force firms (i.e., firm management) to police and investigate themselves and produce evidence of criminal wrongdoing.

The Justice Department seems to play into the hands of its critics. Declaring a "bold" but not really new effort to prosecute more individual cases confirms the misapprehension that more corporate managers would be in prison if only prosecutors had tried harder. Such a declaration leaves unnoticed the fundamental barrier: criminal law, the foundations of which are controlled, even still in this age of overcriminalization and discretion, more by Americans and their legislators than by prosecutors.

\footnotetext{
${ }^{47}$ U.S. Dep’t of Justice, U.S. Attorney’s Manual § 9-28.000; United States Secs. \& Exchange Comm'n Exchange Act Release No. 44969 (Oct. 23, 2001) (“Seaboard Report”).

${ }^{48}$ U.S. Dep't of Justice, Memorandum of Deputy Attorney General Sally Quillian Yates to Assistant Attorneys General and United States Attorneys, Sept. 9, 2015.
} 


\subsection{OPTIMIZING A SECOND-BEST INSTRUMENT}

Understanding corporate criminal liability as a tool for deterring criminally bad management is not only a path to a more complete positive account of corporate criminal liability's place in American law. The perspective also provides guidance for normative analysis.

If an attractive theory of corporate criminal liability is that it can be used to influence senior people to manage firms so as to prevent, and certainly not enable, criminal violations by employees, then its practice should seek to optimize that influence. Future analysis and research should pursue the work of scholars, some of them economists, who have long evaluated the Justice Department's prosecution work on this score (Arlen and Kraakman 1997).

Firms should be rewarded with no prosecution, or lenient settlement, when corporate crimes are committed notwithstanding best efforts. (Prosecutors must beware hindsight bias.) Firms should be punished more harshly when corporate crimes result from bad management. Self-reporting and cooperation in prosecution must continue to earn some reward, lest the Justice Department's enforcement program virtually shut down. But malfeasance that is genuinely institutional must be met with punitive sanctions no matter how well managers respond when the firm gets caught.

The difficulties with such enforcement programs lie, of course, in their details, which require separate treatment from this discussion. Much of the evaluation of the relationship between corporate crime and the corporate institution, including firm management, turns on soft and holistic considerations of institutional culture, which are highly situational and fit poorly with traditional forms of legal doctrine. The much-lamented prosecutorial discretion in this field may be unavoidable. But that discretion can still be rigorously analyzed and critiqued, and perhaps even controlled with law.

Meanwhile, there is some promise that the Justice Department has been at least a little responsive to normative analysis. Towards the end of the last administration, leaders of the Criminal Division committed in principle to greater clarity, transparency, and rigor in the process of evaluating firms' compliance efforts and the relationship of those efforts to decisions whether to prosecute, not prosecute, require a conviction or guilty plea, extend favorable settlement terms, and the like. ${ }^{49}$

\footnotetext{
${ }^{49}$ U.S. Dep’t of Justice, Remarks of Assistant Attorney General Leslie R. Caldwell, N.Y.U. School of Law Program on Corporate Compliance and Enforcement, Apr. 17, 2015; Compliance Counsel to Help DOJ Decide Whom to Prosecute, Wall St. J. RisK \& COMPLianCE J., July 30, 2015.
} 


\section{Conclusion}

Corporate crime is an institutional problem. Changing institutions requires changing the behavior of the people who control them. With large corporations, those people are the senior managers. There are many legal and non-legal instruments for influencing senior corporate managers, as the vastness of the field of corporate law attests. Most of the time, however, the only such tool that involves criminal law is corporate criminal liability. This is because individual criminal liability, in its basic structure, does not fit the problem of bad management that produces corporate crime. Law could be reformed to create such fit only with radical changes that lie beyond likely current American consensus. Meanwhile, corporate criminal liability as practiced in the federal system is an available - if not optimal, and certainly not yet optimized - tool for dealing with criminally bad management.

\section{REFERENCES}

Alexander, Larry and Kimberly Kessler Ferzan (2009), Crime and Culpability: A Theory of Criminal Law, Cambridge University Press.

Alschuler, Albert (2009), Two Ways to Think About the Punishment of Corporations, American Criminal Law Review, 46, 1359-1392.

Arlen, Jennifer (1994), The Potentially Perverse Effects of Corporate Criminal Liability, Journal of Legal Studies, 23, 833-67.

Arlen, Jennifer (2012), Corporate Criminal Liability: Theory and Evidence, in K. Hylton and A. Harel, eds., Research Handbook on Criminal Law.

Arlen, Jennifer and William Carney (1992), Vicarious Liability for Fraud on Securities Markets: Theory and Evidence, University of Illinois Law Review, 1992, 691-740.

Arlen, Jennifer and Marcel Kahan (2017), Corporate Governance Regulation Through Nonprosecution, University of Chicago Law Review (forthcoming).

Arlen, Jennifer and Reinier Kraakman (1997), Controlling Corporate Misconduct: An Analysis of Corporate Liability Regimes, New York University Law Review, 72, 687-779.

Arlen, Jennifer and Cindy Alexander (2017) [in this volume on reputational sanctions].

Baer, Miriam (2009), Governing Corporate Compliance, Boston College Law Review, 50, 949-1019.

Baker, Tom and Sean Griffith (2010), Ensuring Corporate Misconduct, Chicago: University of Chicago Press. 
Barstow, David (2012), Vast Mexico Bribery Case Hushed-Up by Wal-Mart after TopLevel Struggle, New York Times.

Beale, Sara (1994), Too Many and Yet Too Few: New Principles to Define the Proper Limits of Federal Criminal Jurisdiction, Hastings Law Journal, 46, 979-1018.

Becker, Gary, Crime and Punishment: An Economic Approach (1968), Journal of Political Economy, 76, 169-217.

Bhagat, Sanjai, Brian Bolton, and Roberta Romano (2014), Getting Incentives Right: Is Deferred Bank Executive Compensation Sufficient?, Yale Journal on Regulation, 31, 523-564.

Bucy, Pamela (1990), Corporate Ethos: A Standard for Imposing Corporate Criminal Liability, Minnesota Law Review, 75, 1095-1184.

Buell, Samuel (2006), The Blaming Function of Entity Criminal Liability, Indiana Law Journal, 81, 473-537.

Buell, Samuel (2007), Criminal Procedure within the Firm, Stanford Law Review, 59, 1613-1670.

Buell, Samuel (2011), What is Securities Fraud?, Duke Law Journal, 61, 511-581.

Buell, Samuel (2013), Liability and Admissions of Wrongdoing in Public Enforcement of Law, University of Cincinnati Law Review, 82, 505-522.

Buell, Samuel (2014), Is the White Collar Offender Privileged?, Duke Law Journal, 63, 823-889.

Buell, Samuel (2016), Capital Offenses: Business Crime and Punishment in America's Corporate Age, New York: W.W. Norton \& Co.

DiMento, Joseph, Gilbert Geis, and Julia Gelfand (2000), Corporate Criminal Liability: A Bibliography, Western State University Law Review, 28, 1-64.

Dressler, Joshua (2012), Understanding Criminal Law, LexisNexis.

Efendi, Jan, Anup Srivastava and Edward P. Swanson (2007), Why Do Corporate Managers Misstate Financial Statements? The Role of Option Compensation and Other Factors, Journal of Financial Economics, 85, 667-708.

Eisinger, Jesse (2014), Why Only One Top Banker Went to Jail for the Financial Crisis, New York Times Magazine.

Fischel, Daniel and Alan Sykes (1996), Corporate Crime, Journal of Legal Studies, 25, 319-349. 
Garrett, Brandon (2014), Too Big to Jail, Cambridge: The Belknap Press of Harvard University Press.

Hamdani, Assaf and Reinier Kraakman (2007), Rewarding Outside Directors, Michigan Law Review, 105, 1677-1711.

Henning, Peter (2014), A New Crime for Corporate Misconduct?, Mississippi Law Journal, 84, 43-90.

Kahan, Dan (1997), Social Influence, Social Meaning, and Deterrence, Virginia Law Review, 83, 349-395.

Karpoff, Jonathan, Lee, Scott, and Martin, Gerald (2008), The Cost to Firms of Cooking the Books, Journal of Financial and Quantitative Analysis, 43, 581-612.

Karpoff, Jonathan and John Lott (1993), The Reputational Penalty Firms Bear from Committing Criminal Fraud, Journal of Law and Economics, 36, 757-802.

Kelman, Mark (1981), Interpretive Construction in the Substantive Criminal Law, Stanford Law Review, 33, 591-673.

Khanna, V.S. (1996), Corporate Criminal Liability: What Purpose Does It Serve?, Harvard Law Review, 109, 1477-1534.

Kornhauser, Lewis (1982), An Economic Analysis of the Choice Between Enterprise and Personal Liability for Accidents, California Law Review, 70, 1345-1392.

LaFave, Wayne (2010), Criminal Law, St. Paul: West.

Laufer, William (1994), Corporate Bodies and Guilty Minds, Emory Law Journal, 43, 647-730.

Martinez, Jenny (2007), Understanding Mens Rea in Command Responsibility, Journal of International Criminal Justice, 5, 638-664.

Miller, Geoffrey (2014), The Law of Governance, Risk Management, and Compliance, New York: Walters Kluwer.

Partnoy, Frank (2011), Should Some Bankers be Prosecuted?, New York Review of Books.

Rakoff, Jed, (2014), The Financial Crisis: Why Have No High-Level Executives Been Prosecuted?, New York Review of Books.

Schwartz, Steven (2015), Misalignment: Corporate Risk-Taking and Public Duty, Social Sciences Research Network (working paper), ssrn.com. 
Sepinwall, Amy (2014), Responsible Shares and Shared Responsibility: In Defense of Responsible Corporate Officer Liability, Columbia Business Law Review, 2014, 371-419.

Simons, Ken (2012), Statistical Knowledge Deconstructed, Boston University Law Review, 91,

Sykes, Alan (1984), The Economics of Vicarious Liability, Yale Law Journal, 93, 12311280 .

Taibbi, Matt (2014), The Divide, New York: Spiegel \& Grau.

Valukas, Anton (2014), Report to Board of Directors of General Motors Company Regarding Ignition Switch Recalls, New York: Jenner \& Block.

Walsh, Brian and Tiffany Joslyn (2010), Without Intent: How Congress Is Eroding the Criminal Intent Requirement in Federal Law, The Heritage Foundation.

Weisselberg, Charles and Su Li (2011), Big Law's Sixth Amendment: The Rise of Corporate White-Collar Practices in Large U.S. Law Firms, Arizona Law Review, 53, 1221-1300. 